\title{
NOTES
}

\section{COLLATERAL DAMAGE? THE IMPACT OF NATIONAL SECURITY CRISES ON THE FOURTH AMENDMENT PROTECTION AGAINST UNREASONABLE SEARCHES}

Sara A. Chandler

\author{
INTRODUCTION
}

There are more instances of the abridgment of the freedom of the people by gradual and silent encroachments of those in power than by violent and sudden usurpations.

James Madison $^{1}$

In January 2001, hidden cameras scanned the faces of all 100,000 Super Bowl attendees as they entered the stadium. ${ }^{2}$ Unbeknownst to the attendees, the scanned images were then compared with state, local, and FBI files of known criminals and terrorists. ${ }^{3}$ Was this measure justified in the interest of public safety and national security, or did it represent an unconstitutional violation of one's fundamental right to privacy?

Eight months later, the tragedy of September 11th exposed America's vulnerability to international terrorism. In response, Congress quickly passed the Uniting and Strengthening America by Providing Appropriate Tools

* J.D., University of Pittsburgh, 2006; M.S. Carnegie Mellon University, 2006; B.A. Indiana University—Bloomington, 1998.

1. James Madison, Speech in the Virginia Ratifying Convention in Defense of the Constitution (June 6, 1788), in JAMES MADison: Writings 354 (Jack N. Rakove ed., 1999).

2. Louis Sahagun \& Josh Meyer, Secret Cameras Scanned Crowd at Super Bowl for Criminals, L.A. Times, Feb. 1, 2001, at A1.

3. Id. 
Required to Intercept and Obstruct Terrorism Act of 2001 (PATRIOT Act), ${ }^{4}$ which was renewed in March 2006. ${ }^{5}$ The PATRIOT Act purportedly provides some important national security measures such as the removal of a statute of limitations for terrorism offenses. ${ }^{6}$ However, the measures come at a cost by increasing government's ability to conduct unwarranted surveillance on innocent persons without incorporating sufficient safeguards to prevent abuses of power. ${ }^{7}$ Several scholars, politicians, and media outlets have criticized the tactics that PATRIOT Act proponents utilized to secure the Act's passage as "undemocratic." Such tactics included providing little opportunity for debate and working in closed sessions, allowing proponents to secure the votes of congressmen who had not thoroughly read the proposed legislation.'

Although Congress has the power to "make all Laws which shall be necessary" 10 to protect national security, the Fourth Amendment gives the people the right to be secure against unreasonable searches and seizures. ${ }^{11}$ Protecting national security at the expense of civil liberties and vice versa is dangerous. A nation where the quest for security suffocates liberty experiences totalitarianism: a nation where personal liberty is maintained at the expense of national security experiences instability in the form of increased vulnerability to outside attack. Either extreme weakens a nation and threatens liberty. ${ }^{12}$

Examples such as the 2001 Super Bowl and the PATRIOT Act illustrate an inherent constitutional tension between preserving national security and

4. Uniting and Strengthening America by Providing Appropriate Tools Required to Intercept and Obstruct Terrorism Act of 2001 [hereinafter USA PATRIOT Act], Pub. L. No. 107-56, 115 Stat. 272 (2001) (enacted Oct. 26, 2001).

5. USA PATRIOT Improvement and Reauthorization Act of 2005 [hereinafter USA PATRIOT Reauthorization Act], Pub. L. No. 109-177, 120 Stat, 192 (2006) (enacted Mar. 9, 2006).

6. See USA PATRIOT Act $\$ 809$.

7. See Jules Lobel, The War on Terrorism and Civil Liberties, 63 U. PITT. L. Rev. 767, 778-90 (2002), for a discussion of how civil liberties have been restricted in the post-9/11 environment.

8. See, e.g., 147 Cong. Rec. E1897-01 (daily ed. Oct. 16, 2001) (statement of Rep. Diana DeGette); James Kuhnhenn, House Passes Counter-Terrorism Bill, Knight-Ridder/Trib. Bus. News (Wash.), Oct. 25, 2001 (noting Representative Barney Frank's (D-Mass.) comment that the bill was "debated in the most undemocratic way possible").

9. See, e.g., Beryl A. Howell, Seven Weeks: The Making of the USA PATRIOT Act, 72 Geo. Wash. L. Rev. 1145, 1146-78 (2004); Declan McCullagh, USA Act Stampedes Through, Wired News, Oct. 25, 2001, at http://www.wired.com/news/conflict/0,2100,47858,00.html?tw=wn_story_page_prev2.

10. U.S. CONST. art. I, $\S 8$, cl. 18 .

11. U.S. CONST. amend. IV.

12. See Michael Ignatieff, Lesser Evils, N.Y. Times, May 2, 2004, § 6 (Magazine), at 46. Furthermore, maintaining personal liberty at the expense of national security leaves the country increasingly vulnerable to attack by hindering the implementation of reasonable safeguards necessary for the country's protection. Exploitation of the country's security intrinsically results in less freedom. 
preventing unwarranted governmental encroachment on civil liberties. Although the oft-maligned PATRIOT Act has sparked substantial debate, the erosion of civil liberties arguably began long before its passage, and threatens to continue even if particularly controversial elements of the PATRIOT Act are eventually permitted to expire. ${ }^{13}$ Finding a proper balance so national security and privacy interests can co-exist harmoniously presents a difficult challenge given the divisiveness of the issue.

This Note explores the importance of guarding national security while simultaneously preserving fundamental civil liberties. It examines the tension between Fourth Amendment privacy protections and the need for the government to obtain information in order to protect citizens against acts of terrorism. Specifically, this Note proposes the institution of a framework for analyzing the constitutionality of legislative actions affecting national security and privacy. Given the breadth of Fourth Amendment jurisprudence, this Note focuses primarily on privacy in the context of searches. The test encompasses an intermediate scrutiny approach with the addition of reasonable time, place, and manner restrictions on Fourth Amendment privacy encroachments.

Part I of this Note hypothesizes that the concepts of liberty and privacy are interrelated but not synonymous. This section also addresses the common responses of the Executive, Legislative and Judicial branches of the federal government to national crises in order to illustrate the expansion and contraction of civil liberties in response to national security concerns. ${ }^{14}$

Part II examines the development of fundamental Fourth Amendment law and explores the inherent historical tensions between privacy and national security in the context of the Fourth Amendment. The Fourth Amendment

13. Section 224 of the USA PATRIOT Act contained a list of provisions originally subject to sunset on December 31, 2005. However, in its passage of the USA PATRIOT Reauthorization Act, Congress extended the sunset date to December 31, 2009 for some provisions, see, e.g., USA PATRIOT Reauthorization Act $\S 102$ (b) (extending the sunset date for Sections 205 and 215 of the USA PATRIOT Act), while repealing the sunset clause for all other PATRIOT Act provisions, see id. § 102(a) (repealing $\S 224$ of the USA PATRIOT Act). Thus, many provisions originally subject to sunset on December 31 , 2005 are now permanent. In addition, in December 2004, Congress passed a variety of "little-noticed" measures "broaden[ing] the government's power to conduct terrorism investigations, including . . . loosen[ing] standards for FBI surveillance warrants. ..." Dan Eggen, Measure Expands Police Powers, WASH. Post, Dec. 10, 2004, at A1. Such actions indicate that the concern for a proper balance between civil liberties and national security will exist regardless of Congress's future actions regarding the PATRIOT Act.

14. See Richard A. Posner, The Best Offense, New Republic (Sept. 2, 2002) (reviewing Alan M. Dershowitz, Why Terrorism Works: Understanding the Threat, Responding to the Challenge (2002)). 
discussion emphasizes a doctrinal division between cases focusing on privacy interests versus those impacting national security.

Part III details the intermediate scrutiny framework and applies it to selected provisions of the PATRIOT Act. This section assesses whether legislation such as the PATRIOT Act presents truly "grave threat[s]" to civil liberties or if such legislation represents a "measured, responsible, and constitutional approach" to the very real threat of terrorism. ${ }^{15}$ Finally, this section utilizes the proposed framework in order to assess arguments concerning perceived erosions of civil liberties occurring both before and after the passage of the PATRIOT Act.

\section{The Effect of National Security Crises on Conceptions of LIBERTY}

Safety from external danger is the most powerful director of national conduct. Even the ardent love of liberty will, after a time, give way to its dictates. The violent destruction of life and property incident to war, the continual effort and alarm attendant on a state of continual danger, will compel nations the most attached to liberty to resort for repose and security to institutions which have a tendency to destroy their civil and political rights. To be more safe, they at length become willing to run the risk of being less free.

Alexander Hamilton ${ }^{16}$

National security crises have historically had a profound impact on civil liberties. The natural response by both the public and the government to a crisis involves preserving national security at all costs, even if the means of preservation result in an unconstitutional restriction of civil liberties. According to Justice Brennan, each national crisis encompasses the same set of problems: the crisis creates a "national fervor" that causes persons to "exaggerate security risks posed by allowing individuals to express civil liberties." Consequently, citizens "become willing to 'temporarily' sacrifice liberty as part of the war effort." 17 Accordingly, citizens frequently accept a larger relinquishment of freedoms than is required to preserve national security. Justice Jackson once stated that traditional freedoms are "less in danger of any sudden overthrow than of being gradually bartered . . . for

15. Capitol Hill Hearing Testimony: Counterterrorism Legislative Review, 108th Cong. (Sept. 22, 2004) (statement of Dan Collins, Assoc. Deputy Attorney Gen. and Chief Privacy Officer, U.S. Dep’t of Justice).

16. The Federalist No. 8, at 114-15 (Alexander Hamilton) (Isaac Kramnick ed., 1987).

17. William J. Brennan, Jr., The Quest to Develop a Jurisprudence of Civil Liberties in Times of Security Crises, Speech at the Law School of Hebrew University, Jerusalem, Israel, at 1 (Dec. 22, 1987), available at $\mathrm{http}: / / \mathrm{www}$.capaa.wa.gov/pdf/brennan.pdf. 
something else on which the public places a higher current value. In this anxiety-ridden time, many are ready to exchange some of their liberties for a real or fancied increase in security against external foes ....."18

Historical reviews of allegedly unconstitutional exercises of governmental power in response to national crises frequently address a subset of the same four events. ${ }^{19}$ In each event, the government implemented measures designed to stifle potential opposition to or obstruction of governmental objectives during times of national crisis.

The first illustration of the tension between national security and civil liberties occurred in 1798 when Congress enacted the Alien and Sedition Acts. ${ }^{20}$ The Acts allowed the President to expel aliens deemed "dangerous to the peace and safety of the United States" ${ }^{\prime 21}$ and declared the publication of "false, scandalous, and malicious" anti-government writings unlawful. ${ }^{22}$ During the passage of the law, the United States had been on the verge of war with France, and Federalists used "rumors of French espionage and sabotage" to justify the Acts. ${ }^{23}$ However, the enactment of the legislation appears to have been the result of political turmoil between the existing political parties: the Federalists and the Republicans. ${ }^{24}$ Many critics of Federalism left the United States because they feared deportation under the Alien Act, and many Republicans were imprisoned under the Sedition Act. ${ }^{25}$ Although both Acts contained sunset clauses,${ }^{26}$ they have since been regarded as unconstitutional "stain[s] on American liberty.",

18. John Lord O’Brian, National Security and Individual Freedom 11-12 (1955).

19. See Paul Rosenzweig, Civil Liberty and the Response to Terrorism, 42 DuQ. L. Rev. 663, 667-70 (2004); see also David Cole, Judging Judicial Review: Marbury in the Modern Era: Judging the Next Emergency: Judicial Review and Individual Rights in Times of Crisis, 101 Мıсн. L. Rev. 2565, 2569-70 (2003) (citing historical events to illustrate how courts poorly guard civil liberties in times of crisis); Jennifer M. Hannigan, Comment, Playing Patriot Games: National Security Challenges Civil Liberties, 41 Hous. L. Rev. 1371, 1374-81 (2004) (describing the federal government's "sorry" history of protecting civil liberties during national crises).

20. An Act Concerning Aliens, 5 Cong. Ch. 58, 1 Stat. 570 (1798); An Act for the Punishment of Certain Crimes Against the United States, 5 Cong. Ch. 74, 1 Stat. 596 (1798).

21. An Act Concerning Aliens, 1 Stat. at 571.

22. An Act for the Punishment of Certain Crimes Against the United States, 1 Stat. at 596-97.

23. Hannigan, supra note 19, at 1376 (citing Brennan, supra note 17, at 2).

24. See, e.g., Rosenzweig, supra note 19, at 667-68.

25. Hannigan, supra note 19, at 1376 (citing Brennan, supra note 17, at 2).

26. See An Act Concerning Aliens, 1 Stat. at 572; An Act for the Punishment of Certain Crimes Against the United States, 1 Stat. at 597.

27. Rosenzweig, supra note 19, at 668. 
A second commonly cited event concerns President Lincoln's infamous suspension of the writ of habeas corpus during the Civil War. ${ }^{28}$ Suspending the writ subjected all persons "guilty of any disloyal practice" to court-martial. ${ }^{29}$ In one example, Major-General Burnside issued a special order imposing a punishment of death on anyone actively sympathetic to the Confederacy. ${ }^{30}$ At a large meeting, Ohio citizen Clement T. Vallandigham allegedly criticized the war as one "not waged for the preservation of the Union, but for the purpose of crushing out liberty and to erect a despotism." 31 Officers arrested Vallandigham at his home and he was subsequently sentenced by a military tribunal for the duration of the war. ${ }^{32}$ The Court determined that they lacked jurisdiction to revise the tribunal's decision, ${ }^{33}$ but ultimately declared President Lincoln's wartime actions unconstitutional shortly following the war's conclusion. ${ }^{34}$

Third, federal authorities prosecuted over 2,000 people during World War I for their opposition to the war in violation of the 1917 Espionage Act. ${ }^{35}$ The Espionage Act permitted the government to "confiscate property, wiretap, search and seize private property, censure writings, open mail and restrict the right of assembly." ${ }^{36}$ The Act was meant to find and punish German spies, but the Act was inherently vague. Thus, the application of the law focused on "agitators" instead of German spies. ${ }^{37}$ The Court affirmed all convictions reviewed during the war; however, it later overturned all. ${ }^{38}$

Fourth, and most notoriously, the Supreme Court upheld the forced relocation and internment of more than 110,000 law-abiding Japanese-American citizens in camps during World War II. ${ }^{39}$ In Korematsu v. United States, the Court stated that the threat Japanese-Americans citizens posed to national security justified the "compulsory" expulsion of those

\footnotetext{
28. See id.; Cole, supra note 19, at 2569-70.

29. See Rosenzweig, supra note 19, at 668 (citing The Collected Works of Abraham Lincoln 436-37 (Roy P. Balser et al. eds., 1955)).

30. Ex parte Vallandigham, 68 U.S. 243, 243 (1864).

31. Id.

32. $I d$.

33. Id. at 251-52.

34. See Ex parte Milligan, 71 U.S. 2 (1866). 217.

35. Rosenzweig, supra note 19, at 668-69; see Espionage Act of 1917, Pub. L. No. 65-24, 40 Stat.

36. William C. Banks \& M.E. Bowman, Executive Authority for National Security Surveillance, 50 Am. U. L. Rev. 1, 22 (2000).

37. $I d$.

38. See Rosenzweig, supra note 19, at 668-69.

39. See Korematsu v. United States, 323 U.S. 214, $223-24$ (1944).
} 
citizens from their homes. In 1988, Congress formally acknowledged "the grave injustice [that] was done to both citizens and permanent resident aliens of Japanese ancestry by the evacuation, relocation, and internment of civilians during World War II"40 and President Reagan offered a formal apology and reparations to the victims. ${ }^{41}$

Each of the noted crises and associated responses focused upon the perceived vulnerability of the United States to traditional threats involving foreign countries or internal factions. The crises also tended to affect First Amendment rights. In the past century, however, conceptions of privacy have evolved exponentially as a result of a technological and societal revolution. ${ }^{42}$ Technological advancements have increased the risk and temptation of unwarranted governmental intrusion while societal liberalization has encouraged citizens to demand less governmental intrusion into their private affairs. In cases involving national security crises, the public at large willingly trades some element of privacy in exchange for security since the value of security increases relative to privacy.

As a result of this shift from the impact of the First Amendment to those affecting privacy, the responses to national crises in today's environment are increasingly likely to raise questions regarding the relationship between the right to privacy and national security. In the post-September 11th environment, the challenge of combating an "asymmetrical threat" where "individuals and subnational organizations harbor murderous grudges but lack a sufficient stake in peace to be deterred by the prospect of retaliation" is coupled with an evolving definition of freedom where privacy is of paramount importance. $^{43}$

The PATRIOT Act is consistent with the aforementioned measures employed during a national crisis. It is particularly striking that the sentiments expressed by civil libertarians today are exactly the same as those echoed during the height of the Red Scare in 1955, where it was claimed that "some of the most damaging of these encroachments [on civil liberties] have been deliberately embodied in the Acts of Congress." ${ }^{44}$ Although the underlying

\footnotetext{
40. Civil Liberties Act of 1988, Pub. L. No. 100-383, 102 Stat. 903.

41. See Rosenzweig, supra note 19, at 669.

42. See, e.g., Orin S. Kerr, The Fourth Amendment and New Technologies: Constitutional Myths and the Need for Caution, 102 Mich. L. REv. 801, 802-05 (2004).

43. Donald A. Dripps, Reflections on the Criminal Justice System after September 11, 2001: Terror and Tolerance: Criminal Justice for the New Age of Anxiety, 1 OHIо ST. J. Crim. L. 9,14 (2003).

44. See O'Brian, supra note 18, at 26-27.
} 
crises have varied, the fears of governmental encroachments on civil liberties are the same.

The PATRIOT Act was designed to remove existing barriers that allegedly prevented government agencies from sharing information and to facilitate government investigations of terrorist activities. ${ }^{45}$ However, many provisions of the PATRIOT Act appear to increase governmental power without adequately safeguarding civil liberties. The most controversial provisions allow the government to (1) conduct "sneak and peek" searches ${ }^{46}$ and (2) access personal information about innocent citizens without their knowledge or consent. ${ }^{47}$

\section{A. The Controversial Provisions}

A "sneak and peek" warrant allows law enforcement officials to conduct a search without providing notice of the search's execution to the affected parties. ${ }^{48}$ Although an argument can be made that such warrants are useful in order to protect the integrity of ongoing criminal investigations, the PATRIOT Act's provisions are extraordinarily vague because they merely require notice "within a reasonable period of [the warrant's execution]" extensions based on "good cause." ${ }^{50}$ PATRIOT Act opponents cite numerous instances where police have mistakenly entered the wrong dwelling without abiding by the "knock and announce rule" and killed an innocent party. ${ }^{51}$ Supporters of the PATRIOT Act, however, claim that the sneak-and-peek provision provides "clear guidelines" to courts and that its elements have been

45. See Craig S. Lerner, The USA PATRIOT Act: Promoting the Cooperation of Foreign Intelligence Gathering and Law Enforcement, 11 Geo. MAson L. Rev. 493, 495 (2003).

46. USA PATRIOT Act $\S 213$, Pub. L. No. 107-56, 115 Stat. 272 (2001).

47. See, e.g., id. $\S 215,505$.

48. See John W. Whitehead \& Steven H. Aden, Forfeiting "Enduring Freedom" for "Homeland Security": A Constitutional Analysis of the USA PATRIOT Act and the Justice Department's AntiTerrorism Initiatives, 51 AM. U. L. Rev. 1081, 1110-11 (2002).

49. The USA PATRIOT Reauthorization Act amended this provision by effectively defining a "reasonable period" as one that does not exceed 30 days; however, this period can be extended upon a showing that the facts of the case warrant a longer period. USA PATRIOT Reauthorization Act $\S 114$, Pub. L. No. 109-177, 120 Stat, 192 (2006). Thus, the amendment does not appear to truly provide any additional protection.

50. USA PATRIOT Act $\S 213$.

51. See Whitehead \& Aden, supra note 48, at 1110 \& n.185. In June 2006, the Supreme Court significantly weakened the level of protection afforded to defendants via the knock and announce rule by holding that the rule does not "require[] the suppression of all evidence found in [a] search." Hudson v. Michigan, No. 04-1360, 2006 U.S. LEXIS 4677, at *5 (U.S. June 15, 2006). 
constitutionally accepted by courts in prior litigation. ${ }^{52}$ Interestingly, some PATRIOT Act supporters have noted that the Bush Administration's original proposal "ignored key limitations created by the courts" by allowing officers to seize property without showing "reasonable necessity" for the seizure. ${ }^{53}$ Although the House of Representatives voted to repeal the sneak-and-peek provision in 2003, ${ }^{54}$ the March 2006 reauthorization of the PATRIOT Act retains this provision. ${ }^{55}$

In terms of accessing personal information about citizens, Sections 215 and 505 of the Act have been frequently criticized as among the most troublesome provisions in light of their infringement on privacy. ${ }^{56}$ Although the title denotes "Business Records," Section 215 allows the federal government to obtain "any tangible thing" without informing the affected individual(s). ${ }^{57}$ Section 505 of the PATRIOT Act permits government officials to obtain telephone records, financial records, and consumer reports. $^{58}$ The only requirement is that the activities be "relevant" to an intelligence investigation. ${ }^{59}$ Supporters note that no evidence exists indicating that the government has abused its authority. ${ }^{60}$ However, the clandestine nature of current government operations in terms of withholding information from the public creates cause for concern. ${ }^{61}$

\section{B. Causes for Concern}

Given the focus on national security, one could logically argue that, with the initial passage and subsequent renewal of the PATRIOT Act, the government is arguably "plac[ing its] conception of the need for national

52. See Howell, supra note 9, at 1186-88.

53. See id.

54. See, e.g., 147 Cong. Rec. H7284-7311 (daily ed. July 22, 2003); Craig Gilbert, Feingold Stalls Patriot Act; He Assails Democrats who "Folded" on Law, Milwaukee J. Sentinel (Wis.), Feb. 16, 2006, at A3.

55. See USA PATRIOT Reauthorization Act $\S 114$, Pub. L. No. 109-177, 120 Stat, 192 (2006) (amending 18 U.S.C. $\S 3103 a$ ).

56. See, e.g., Dahlia Lithwick \& Julia Turner, A Guide to the Patriot Act, Slate, Sept. 8, 2003, http://slate.msn.com/id/2087984/.

57. USA PATRIOT Act $\S 215$.

58. See id. $\S 505$.

59. Id.

60. See Howell, supra note 9, at 1190.

61. Muneer I. Ahmad, A Rage Shared by Law: Post-September 11 Racial Violence as Crimes of Passion, 92 CAL. L. ReV. 1259, 1271 n.36 (2004). 
security ahead of the traditional rights of the individual." ${ }^{962}$ In a speech to the Senate Judiciary Committee in 2001, then-Attorney General John Ashcroft proclaimed that "those who scare peace-loving people with phantoms of lost liberties ... only aid terrorists" by "erod[ing] national unity and diminish[ing the nation's] resolve." ${ }^{93}$ When examined in conjunction with the historical responses to crises, comments such as Ashcroft's naturally fuel speculation that civil liberties have been sacrificed by the hand of an overzealous government. Ashcroft's comments provide a disturbing parallel to the Alien and Sedition Acts in that they both threatened to stifle debate. Given the history of government responses to crises, civil libertarians have valid justifications for their concerns.

Given the underlying concerns and inherent vagueness allegedly underlying the PATRIOT Act, some key factors arguably further illustrate the risks of abuse. First, several of the most controversial provisions were subject to a sunset clause and were set to expire on December 31, 2005, including Section 215; however, the sunset date was subsequently extended to December 31, 2009. Furthermore, several other provisions, including Section 505, were also subject to sunset on December 31, 2005, but the 2006 PATRIOT Act Reauthorization repealed the sunset clause contained in the PATRIOT Act - thus making most of the provisions originally subject to sunset permanent. ${ }^{64}$ In addition, the War on Terror is of indeterminate length ${ }^{65}$ and Congress also recently passed an intelligence package containing the types of reforms that are of concern in the PATRIOT Act. ${ }^{66}$ Thus, the more controversial provisions of the PATRIOT Act could be around for some time to come-in many cases, permanently.

\section{The Judicial Response}

The judicial system has also reacted to the PATRIOT Act's more controversial provisions. ${ }^{67}$ Arguably, the Supreme Court has "function[ed]

62. See O'Brian, supra note 18 , at 26.

63. Eric Lichtblau \& Adam Liptak, Threats and Responses: On Terror, Spying and Guns, Ashcroft Expands Reach, N.Y. Times, Mar. 15, 2003, at A1.

64. See USA PATRIOT Act $\S 224$, Pub. L. No. 107-56, 115 Stat. 272 (2001); see also supra note 12. USA PATRIOT Act $\S 213$ (covering "sneak and peek" warrants) is not subject to the sunset clause.

65. Nat Hentoff, The War on the Bill of Rights and the Gathering Resistance 23 (2003).

66. See supra note 13 and accompanying text.

67. See, e.g., Doe I v. Gonzales, Nos. 05-0570-cv(L) \& 05-4896-cv(CON), 2006 U.S. App. LEXIS 12820, at *3-4 (2d Cir. May 23, 2006) (remanding a case challenging the constitutionality of 18 U.S.C. $\S 2709$ (c) to see if the amended provision violates the First Amendment in light of the USA PATRIOT 
poorly as guardians of liberty" when responding to national crises. ${ }^{68}$ History demonstrates that this observation is true if the judicial system perceives an ongoing imminent threat. However, the judicial system tends to restore the balance between security and privacy once a crisis is perceived to have subsided. Although the new equilibrium may tilt more toward security than it had before the crisis, the judicial system's reactions tend to mirror societal readjustments following national crises.

Even if the entire PATRIOT Act is ultimately deemed unconstitutional or is otherwise discarded, ${ }^{69}$ the analysis contained herein remains relevant. The United States will experience future crises that will shift the balance between national security and privacy. The PATRIOT Act is a mere illustration in this regard. The fact that the judicial system is reacting or may ultimately react to legislation does not render the provisions any less unconstitutional.

\section{Public and Governmental Response to a Crisis}

The fundamental analysis for determining the proper response to each crisis requires a delicate balancing of national security and civil liberty interests. ${ }^{70}$ Numerous legal scholars have noted a recurring theme underlying public and governmental responses to national security crises: Whenever the United States has faced a crisis threatening national security, it has arguably responded overzealously. ${ }^{71}$ However, the government's responses have frequently been commensurate with general public sentiment. ${ }^{72}$

Despite the willingness of citizens to barter civil liberties in times of crises, the balance between national security and privacy is dynamic. This notion is illustrated by the proposal and enactment of actions potentially dismantling selected provisions of the PATRIOT Act. The balance shifts as societal changes occur. Once the public and government feel that a threat has subsided, the balance is restored toward equilibrium.

In addition, the codified restrictions on civil liberties enacted via the PATRIOT Act have potentially been less severe than those resulting from

\footnotetext{
Reauthorization Act). The provision allowed FBI investigators to issue National Security Letters to internet service providers in order to "gain access ... to subscriber information." Id.

68. Cole, supra note 19 , at 2566.

69. Although this seems unlikely.

70. See, e.g., Cole, supra note 19, at 2570; Rosenzweig, supra note 19, at 667.

71. See David Cole, Enemy Aliens, 54 Stan. L. Rev. 953, 955 (2002); Rosenzweig, supra note 19, at 667 .

72. See, e.g., Cole, supra note 19 , at 2568-70.
} 
earlier crises. Today, United States citizens have such strong conceptions of privacy and liberty that the debate remains open regardless of governmental attempts to dissuade discussion.

Furthermore, citizens must relinquish some elements of privacy in order to preserve security. A need for national security negates a notion of pure privacy. The most stringent search and seizure protections concern the home $;{ }^{73}$ by venturing out into the public domain, citizens relinquish some of their right to privacy - the need for increased national security begins to prevail. However, a question exists concerning how much privacy citizens should relinquish. The right to privacy in one's home should be virtually absolute. Ironically, citizens are experiencing an unprecedented level of intrusion that seemingly has little relationship to the nation's security. Much of the intrusion relates to the invention of new technology, which could not realistically have been anticipated by the Constitution's Framers.

As stated by one commentator in 1955 during the height of Communism, "[o]ne of the principal influences which threaten the very existence of democracy is the all-pervasive craving for security at any price. The two wars, the desperate experience of the great depression, and the threat of atomic warfare have all strengthened this desire." ${ }^{\prime 4}$ Such comments are starkly relevant even 50 years later. With each new generation, a new crisis appears that threatens to extinguish liberty. In this generation, the primary crisis is a war waged not by a country but by groups of individuals harboring pure hatred toward the United States. It is a war that is difficult, if not impossible, to entirely defend. Thus, the government needs to retain appropriate tools in its arsenal. However, providing such tools at the expense of civil liberties results in a physically secure country with no freedoms. The current enforcement of national security provisions risks infringing unconstitutionally on privacy interests in a variety of areas. The addition of Fourth Amendment requirements introduces further complexities.

\section{Exploring Privacy Interests in the Fourth Amendment Context}

They that can give up essential liberty to purchase a little temporary safety, deserve neither liberty nor safety.

\section{Benjamin Franklin ${ }^{75}$}

\footnotetext{
73. See Boyd v. United States, 116 U.S. 616, 630 (1886).

74. See O'Brian, supra note 18 , at 7 .

75. Benjamin Franklin, Historical Review of Pennsy lvania (1759).
} 
In order to protect liberty, "every unjustifiable intrusion by the Government upon the privacy of the individual, whatever the means employed, must be deemed a violation of the Fourth Amendment." Fourth Amendment essentially "provides the first line of defense" against unconstitutional government intrusions on privacy. ${ }^{77}$ The Fourth Amendment prohibition against unlawful searches and seizures contains a variety of exceptions that have been fashioned by the judicial process over time. A fundamental division exists between "traditional" searches and seizures and those conducted pursuant to a national security interest. As a result, the Fourth Amendment provides different protections when national security is at stake. Thus, the argued erosion of civil liberties potentially occurs on two distinct, yet interrelated, fronts: traditional Fourth Amendment principles as reflected in Katz $v$. United States ${ }^{78}$ and subsequent cases containing enumerated exceptions, ${ }^{79}$ and adjustments in Fourth Amendment protections in response to national security crises.

\section{A. Traditional Fourth Amendment Principles}

In Olmstead v. United States, the Supreme Court utilized common-law property principles to determine that an "actual physical invasion" was required in order to constitute a Fourth Amendment search. ${ }^{80}$ Thus, the Court did not consider wiretapping conducted outside of a building as a search and consequently denied Fourth Amendment protections to those who had been tapped. ${ }^{81}$ The rationale behind the Olmstead holding concerned the fact that the wiretap did not violate the owner's property rights since "there was no entry of the houses or offices of the defendants." Katz v. United States ${ }^{83}$ allegedly abandoned a property-oriented approach to Fourth Amendment cases. ${ }^{84}$ The case stands for the proposition that police

76. Kerr, supra note 42, at 804 (citing Olmstead v. United States, 277 U.S. 438, 478 (1928) (Brandeis, J., dissenting)).

77. $I d$.

78. Katz v. United States, 389 U.S. 347 (1967).

79. Such exceptions encompass both exceedingly narrow conceptions of privacy and exceedingly narrow conceptions of what actions constitute a "search." See Wayne LaFave, The Present and Future Fourth Amendment, 1995 U. ILL. L. REv. 111, 112-13 (citing cases such as United States v. Miller, 425 U.S. 435 (1976) and United States v. Knotts, 460 U.S. 276 (1983)).

80. Olmstead v. United States, 277 U.S. 438, 466 (1928).

81. See id.

82. Id. at 464

83. 389 U.S. 347 (1967).

84. See LaFave, supra note 79 , at 112 . 
actions constitute searches in instances where an individual has a reasonable expectation of privacy. ${ }^{85}$ If a person "knowingly exposes [information] to the public, even in his own home or office, [it] is not a subject of Fourth Amendment protection. But what he seeks to preserve as private, even in an area accessible to the public, may be constitutionally protected." ${ }^{86}$

Katz provides an "eminently sensible" approach to Fourth Amendment search inquiries given the prevalence of modern technology. ${ }^{87}$ It also provides a strong baseline approach for "typical" searches. ${ }^{88}$ Unfortunately, the Katz rule has been significantly eroded due to the Court's varying conceptions of privacy. In United States v. Miller, the Court held that a person lacks a reasonable expectation of privacy in his financial information kept in bank records. Consequently, that information is not entitled to Fourth Amendment protection. ${ }^{89}$ The Court's rationale focused on the "voluntary convey[ance]" of the information and the "expos[ure] to employees in the ordinary course of business. ${ }^{" 90}$ Furthermore, the Court noted that the congressional purpose for maintaining such records per the Bank Secrecy Act was that such records "have a high degree of usefulness in criminal ... investigations and proceedings." ${ }^{\prime 91}$ Thus, although most individuals would likely argue that an individual can retain a reasonable expectation of privacy even in information that he limitedly, and necessarily, discloses to a third party, this argument failed in Miller - a decision occurring 25 years before the passage of the PATRIOT Act.

Although the Fourth Amendment purportedly "protects people, not places," analyze where persons have a reasonable expectation of privacy. The focus on records kept in a banking institution in Miller is one example of how the concept of "place" continues to play a significant role in Fourth Amendment

\footnotetext{
85. Smith v. Maryland, 442 U.S. 735 (1979); Katz, 389 U.S. at 361 (Harlan. J., concurring).

86. Katz, 389 U.S. at 351.

87. See LaFave, supra note 79, at 112.

88. A "typical" search is one that does not directly impact a national security interest.

89. 425 U.S. 435,442 (1976).

90. Id.

91. 12 U.S.C. $§ 1829 b(a)(1)$ (2000). The PATRIOT Act altered the Bank Security Act by adding a provision noting that such records may also be useful for conducting intelligence activities. See USA PATRIOT Act $\S 358$, Pub. L. No. 107-56, 115 Stat. 272 (2001). The PATRIOT Act is thus not entirely blameworthy in this scenario - the underlying issue concerning the tension between privacy and national security runs much deeper than most persons realize. However, the addition of this provision is troubling because prior examinations of bank records at least occurred in the context of a criminal investigation. This safety net has now been removed.

92. Katz, 389 U.S. at 361 (Harlan, J., concurring).
} 
jurisprudence. Considerations of privacy must examine the role of "place" in determining whether a person has a reasonable expectation of privacy under Katz (and is consequently entitled to Fourth Amendment protection).

The role of "place" and of the types of police actions that constitute a search have varied substantially since the Katz decision. The Court has held that tracking an individual's movements via a transponder placed in a drum of chloroform does not constitute a search. ${ }^{93}$ A person has no reasonable expectation of privacy in an automobile because anyone could potentially acquire the same information by traveling on the same roads. ${ }^{94}$ On the other hand, the Court recently held that the use of a thermal imaging device providing little information other than the amount of heat emanating from one's home constituted a search. ${ }^{95}$ The definition of whether surveillance constitutes a search thus turns on whether a person has a reasonable expectation of privacy in the thing to be searched. Since the privacy a person enjoys in his home is sacrosanct, surveillance providing information or inferences about any activity occurring within the home constitutes a search regardless of the potential utility of the information. A person acting within the privacy of his home is not voluntarily exposing any information to the public, which illustrates the substantial effect that place has on Fourth Amendment jurisprudence.

The Court also utilizes its reasonableness analysis in order to provide a policy justification for imposing a particular rule even in the absence of evidence supporting the rule's implementation. In National Treasury Employees Union v. Von Raab, ${ }^{96}$ the Court held that Customs employees who are involved in the interdiction of illegal drugs or who carry firearms have a "diminished expectation of privacy" regarding the personal intrusion occasioned by a urinalysis. ${ }^{97}$ However, there was no evidence that a problem had ever existed with Customs employees utilizing illicit drugs. ${ }^{98}$ Essentially, the Court noted that since "the Customs Service is [the] Nation's first line of defense against one of the greatest problems affecting the health and welfare of our population" and that "Customs officers have been targets of bribery by

93. United States v. Knotts, 460 U.S. 276, 277, 281-82 (1983).

94. Id.

95. Kyllo v. United States, 533 U.S. 27, 34-35 (2001).

96. 489 U.S. 656 (1989).

97. Id. at 672 .

98. Id. at 683-84 (Scalia, J., dissenting). 
drug smugglers," then the "Government has a compelling interest" in subjecting the aforementioned Customs employees to drug testing. ${ }^{99}$

The purpose of this Note is not to criticize the Court for basing such decisions on policy justifications; however, the understanding of the Court's rationale in cases where it finds a strong public policy justification is critical for understanding the long history leading up to current concerns. Regardless of the result in a given case, the logic employed by the Court introduces the very realistic possibility that a person has a diminished expectation of privacy in any circumstance the government deems relevant to public policy-the determination is at the whim of the Court or the legislature. It is this uncertainty and lack of safeguards that is most troubling.

Basic Fourth Amendment law grows infinitely more complicated with the introduction of the "probable cause" and "reasonable suspicion" concepts. Although probable cause is required in order to secure a search warrant, ${ }^{100}$ the probable cause requirement does not apply to all searches. ${ }^{101}$ In fact, one legal scholar has noted that "the current state of the law seems to be that warrants are required only for residential searches." 102 As a result of this doctrinal complexity, officers could not search the computer of alleged terrorist Zacharias Moussaoui since they lacked probable cause (despite the potentially grave effect on national security); ${ }^{103}$ however, an officer can conduct drug testing on schoolchildren who choose to participate in extracurricular activities absent any suspicion whatsoever. ${ }^{104}$ It has been suggested that this irony stems from the fact that probable cause is a "fixed" standard and that the constitutionality of searches that persons in the United States experience on a daily basis turns on "the reasonableness of the search, factoring in the degree of intrusion and the gravity of the investigated offense" - not on probable cause. ${ }^{105}$ The proliferation of exceptions to the probable cause standard has the unfortunate effect of not protecting citizens from the most critical threats by focusing on domestic policy objectives such as the War on Drugs and drunk driving. Although these are important objectives, the Court has

99. Id. at 668-69 (majority opinion).

100. U.S. CONST. amend. IV.

101. See Nola K. Breglio, Leaving FISA Behind: The Need to Return to Warrantless Foreign Intelligence Surveillance, 113 YALE L.J. 179, 210 (2003) (noting that the Framers intended "a regime of warrantless searches").

102. Craig S. Lerner, The Reasonableness of Probable Cause, 81 TEx. L. REv. 951, 955 (2003).

103. Id. at 961 .

104. See N.J. v. T.L.O., 469 U.S. 325,340 (1985).

105. Lerner, supra note 102, at 955-56. 
arguably lost sight of how to prioritize and define the "special needs" of law enforcement.

\section{B. The Development of Fourth Amendment Jurisprudence as it Relates to National Security Concerns}

The Katz Court deliberately left a significant loophole in the handling of searches involving national security issues. In a footnote buried toward the end of the majority opinion, the Court noted that the issue of whether or not safeguards "would satisfy the Fourth Amendment [in cases involving national security] is a question not presented by this case." 106 The Court addressed the national security nexus in United States v. United States District Court [hereinafter Keith] ${ }^{107}$ In Keith, the defendant had been charged with bombing a Central Intelligence Agency (CIA) office. ${ }^{108}$ The Court examined whether the President, via the Attorney General, had the constitutional authority to conduct electronic surveillance in national security matters absent a warrant. ${ }^{109}$ Although the Court noted the need for "sensitivity" regarding "the Government's right to protect itself from unlawful . . . attack and . . the citizen's right to be secure in his privacy against unreasonable Government intrusion," it held that the warrantless surveillance constituted a search in violation of the defendant's Fourth Amendment rights despite the significant national security concerns associated with the case. ${ }^{110}$ In reaching its holding, the Court crafted a balancing test, asking whether citizens' privacy needs could better be protected by requiring a warrant and whether a warrant requirement would frustrate the Government's efforts to protect itself. ${ }^{11}$

Interestingly, the Keith Court twice noted that the warrant requirement in national security cases applied only to domestic surveillance - not foreign intelligence. ${ }^{112}$ Furthermore, the Court provided room for flexibility concerning foreign surveillance scenarios by accepting the potential congressional creation of "different standards" that "may be compatible with the Fourth Amendment if ... reasonable both in relation to the legitimate need

106. Katz v. United States, 389 U.S. 347,359 n.23 (1967).

107. United States v. United States Dist. Court [hereinafter Keith], 407 U.S. 297 (1972).

108. Id. at 299.

109. $I d$.

110. $I d$.

111. Id. at 314-15.

112. See Breglio, supra note 101, at 184 \& n.27 (citing Keith, 407 U.S. at 308-09 \& n.8, 321-22). 
of Government for intelligence information and the protected rights of . . citizens." 113

Given the complexities involved in the development of Fourth Amendment law, it is difficult to prescribe a test encompassing all of the rules and exceptions. However, it would be impracticable and unrealistic to discard all existing Fourth Amendment law. Thus, the key becomes one of incorporating various safeguards to prevent an overextension of governmental power while simultaneously not crippling governmental efforts to protect the nation. The two doctrinal approaches and United States history permit a conclusion that although national security crises generally result in temporary restrictions on civil liberties, the advent of new technologies and the proliferation of Fourth Amendment exceptions potentially creates a greater risk of unwarranted government intrusion in day-to-day activities.

\section{Balancing National Security and Privacy}

Experience should teach us to be most on our guard to protect liberty when the
Government's purposes are beneficent. Men born to freedom are naturally alert to repel
invasion of their liberty by evil-minded rulers. The greatest dangers to liberty lurk in
insidious encroachment by men of zeal, well-meaning but without understanding.
Justice Louis Brandeis ${ }^{114}$

Part I noted that the judiciary, as constitutional reviewers of the law, has historically played a significant role in restoring the equilibrium between security and privacy. However, courts tend to delay action until the underlying crisis subsides. ${ }^{115}$ The restoration of the equilibrium can likely be attributed to a combination of court action and societal shifts. Unfortunately, the advent of new technologies risks an increasing erosion of privacy rights. Instead of employing a strictly hindsight approach that reviews legislation after any ensuing damage has been done, a framework must be conceived that can be utilized at both the beginning of an applicable legislative process and during judicial review of a challenged law or action.

\section{A. Approaches to a Fourth Amendment Analysis}

The interaction between Fourth Amendment law and the natural tension between national security and privacy creates complexities that are difficult

113. Keith, 407 U.S. at 322-23.

114. Olmstead v. United States, 277 U.S. 438, 479 (1928) (Brandeis, J., dissenting).

115. See supra text accompanying notes $20-41$. 
to address via a simple framework. The problem is essentially two-fold involving both (1) the balance between privacy and national security and (2) the proper application of Fourth Amendment principles. As explained in detail earlier, Fourth Amendment jurisprudence offers some insight into the confusion and concerns. The balancing test in Keith provides some guidance by articulating an analytical framework: ${ }^{116}$ however, it left a substantial loophole by explicitly excluding foreign intelligence cases. ${ }^{117}$ Furthermore, Fourth Amendment jurisprudence has been riddled with many rules and exceptions. The judicial system has perpetuated the tension between national security and privacy interests by fashioning standards commensurate with government's desired public policy objectives even if the relationship to national security is tenuous. ${ }^{118}$ The judicial system simply applies a quick fix to each situation it encounters by establishing a new, often incomplete, framework instead of delving into the root of the problem and attempting to analyze the proper balance between security and privacy in the given context.

Furthermore, although several authors have abstractly noted an inherent balance between privacy and national security or have vaguely proposed a balancing test, most either get lost in the intricacies of the complex arguments and lose sight of the balancing component or design a balancing test without considering the complexities of existing Fourth Amendment law.

One proposed approach articulates a tolerance standard. ${ }^{119}$ Although the author states that reasonable citizens accept less privacy given the threat of terrorism, the author does not define what the tolerance standard actually entails. ${ }^{120}$ Instead, the focus of the discussion centers on reasons why liberals and conservatives should move to a tolerance standard. ${ }^{121}$ The work identifies the extremes of a "liberal fantasy" and conservative "overcriminalization" and notes that the country should move to the "substitution of tolerance for privacy" as a middle ground. ${ }^{122}$ Instead of providing an analytical framework, the work calls for a nation where "privacy is greatly diminished." 23

A second approach articulates a "one step lower" standard for assessing the constitutionality of present and future legislation passed in the wake of

116. See Keith, 407 U.S. at 314-15.

117. See supra text accompanying note 101 .

118. See, e.g., N.J. v. T.L.O., 469 U.S. 325, 340 (1985).

119. Dripps, supra note 43, at 42-43.

120. Id. at $30-31$.

121. Id. at 30 .

122. Id. at $30,43$.

123. Id. at 43 . 
national security crises. ${ }^{124}$ The test assesses each piece of legislation with an intermediate scrutiny standard, determines the appropriate standard for review absent a national security crisis, and then applies the next-lowest test. ${ }^{125}$ Thus, a situation typically requiring strict scrutiny would be subject to intermediate scrutiny and a situation typically requiring intermediate scrutiny would be subject to rational basis treatment. ${ }^{126}$ Unfortunately, this test keeps the existing framework entirely intact and merely lessens the standard. Furthermore, applying a "one step lower" test risks the removal of critical race-based protections. For example, the government could theoretically devise a means to search Arab-Americans in the interest of national security. Such profiling under the one step lower test would be subject to intermediate instead of strict scrutiny even though the true intention of the search may be unclear. Thus, the government could then conduct searches based largely on race without showing a compelling government interest.

A possible alternative solution is to apply an intermediate scrutiny approach with the addition of reasonable time, place, and manner restrictions on Fourth Amendment privacy encroachments. Exceptions should be limited to situations where a security breach could result in mass death or imminent danger. This test would support the conduction of suspicionless searches in places where one does not have a reasonable expectation of privacy. Furthermore, the test would allow for a dynamic balance by accounting for societal trends while simultaneously providing safeguards.

The utilization of reasonable time, place, and manner restrictions draws from First Amendment jurisprudence. In Clark v. Community for Creative Non-Violence, the Court noted that expression was "subject to reasonable time, place, or manner restrictions." ${ }^{27}$ In the First Amendment context, the government may place content-neutral restrictions on speech provided they are narrowly tailored and leave ample opportunity for alternative methods of communication. ${ }^{128}$ The proposed Fourth Amendment application would apply reasonable time, place, and manner restrictions to the government's actions that have the potential to shift the balance between national security and privacy.

124. Jacob R. Lilly, Note, National Security at What Price?: A Look into Civil Liberty Concerns in the Information Age under the USA PATRIOT Act of 2001 and a Proposed Constitutional Test for Future Legislation, 12 CORNELL J. L. \& PuB. POL'y 447, 467 (2003).

125. $I d$.

126. $I d$.

127. 468 U.S. 288,293 (1984).

128. $I d$. 
Reasonable time, place, and manner considerations include whether a search is suspicionless, the potential damage that could result from a terrorist attack, the public nature of the location affected, and the type of information/surveillance sought. If the government wants to hypothetically examine library patron records ${ }^{129}$ with no suspicion, such action would not be permissible. On the other hand, if the government receives a credible warning threatening a terrorist attack during the Super Bowl, then cross-checking attendees against a federal database may be permissible provided the information is solely used for the matter under investigation or other felonies (and not petty criminal offenses). ${ }^{130}$ The proposed framework naturally incorporates the historical development of Fourth Amendment jurisprudence yet encourages careful consideration of complex issues that will likely arise in the future.

The core modifier of "time, place, and manner" consists of a reasonableness standard. Under a traditional reasonableness standard, one must assess "the degree to which [the action] intrudes upon an individual's privacy and . . . the degree to which it is needed for the promotion of legitimate governmental interests." ${ }^{31}$ National security is a legitimate governmental interest. However, if a restriction or action substantially intrudes on an individual's privacy yet has only a tenuous relationship to preserving national security, then the action would be deemed unreasonable under this framework. One example concerns communications between attorneys and their clients. ${ }^{132}$ When a person speaks with an attorney, he or she would naturally regard governmental eavesdropping to be an unwarranted intrusion on his or her privacy rights. ${ }^{133}$ If the government can eavesdrop on communications between attorneys and clients, then an individual accused of a crime loses his or her basic constitutional protections. However, the Justice Department under John Ashcroft imposed a rule allowing the government to monitor private conversations between attorneys and their clients in federal correction institutions. ${ }^{134}$ The rule applies to all incarcerated persons, and permits the government to eavesdrop without probable cause. ${ }^{135}$ Attorney

129. See generally Robert A. Pikowsky, An Overview of the Law of Electronic Surveillance Post September 11, 2001, 94 LAw LiBR. J. 601, 617-20 (2002).

130. See supra text accompanying notes 2-3.

131. Wyoming v. Houghton, 526 U.S. 295, 300 (1999).

132. See Whitehead \& Aden, supra note 48, at 1116.

133. A person could also view the eavesdropping to be a violation of his or her Sixth Amendment right to counsel. $I d$.

134. See id.

135. Id. 
Lynne Stewart unsuccessfully argued that the government's interceptions of her conversations with her client violated her Fourth Amendment privacy rights. ${ }^{136}$ The government did not deny that Stewart had a reasonable expectation of privacy, yet claimed that the surveillance satisfied Fourth Amendment requirements. ${ }^{137}$ The court agreed with the government. ${ }^{138}$

This reasonableness analysis should also be conducted with an overarching consideration of whether society would consider an individual's expectation of privacy to be reasonable given the totality of circumstances. ${ }^{139}$ However, a tension exists given the natural psychological reactions of people to traumatic events which may prevent individuals from making rational choices. A risk exists that citizens could potentially be duped. Although the percentage of individuals believing that the Bush Administration is going too far by restricting civil liberties in order to fight terrorism increased from $11 \%$ in January 2002 to $28 \%$ in November 2003, the percentage believing the PATRIOT Act went too far held steady at approximately $25 \%$ during this same period. ${ }^{140}$ This information reflects a concern that the government is going too far in terms of restricting civil liberties, yet the public appears to be placing the majority of the blame on partisan politics. In this instance, the public is cognizant of the risks yet, given President Bush's November 2004 reelection, did not yet view the problem as serious enough to warrant the ouster of the existing administration.

The framework's time element should consider the proximity to the anticipated or actual crisis. In the First Amendment context, the government can provide reasonable time restrictions on the communication of speech. ${ }^{141}$ Under the Fourth Amendment context, the time element would alter the appropriateness of certain actions based on their proximity to the event. A governmental action occurring near the time of the event is more likely to be found reasonable than one occurring much later. Under the Fourth Amendment, for example, officers may conduct a search incident to arrest. ${ }^{142}$ A search incident to arrest occurs immediately upon arrest - it is in close proximity to the event. On the other hand, maintaining a continuously high

136. United States v. Sattar, 02 Cr. 395 (JGK), 2003 U.S. Dist. LEXIS 16164, at*46 (S.D.N.Y. Sept. 15, 2003).

137. $I d$.

138. $I d$.

139. See Katz v. United States, 389 U.S. 347, 361 (1967) (Harlan, J., concurring).

140. Darren K. Carlson, The Gallup Organization, Far Enough? Public Wary of RESTRICTED LiBERTIES (2004)

141. See Ward v. Rock Against Racism, 491 U.S. 781, 802-03 (1989).

142. See, e.g., N.Y. v. Belton, 453 U.S. 454 (1981). 
level of restrictions affecting privacy rights for years after a triggering event may become progressively less reasonable, particularly if the associated threat dissipates during that period.

In terms of place, people have a reasonable expectation of privacy in their homes. The protection decreases in public areas. A person does not have a reasonable expectation of privacy in information he knowingly exposes or whatever he subjects to "plain view." One factor that the courts have dismissed is the fact that people often expose information to limited parties out of economic necessity. Such information, if mishandled, could result in identity theft or misuse. A person would have a reasonable expectation of privacy in this information that should not be jeopardized absent reasonable suspicion of wrongdoing.

The prospect of a national ID card system also provides a useful example regarding place restrictions. The prospective institution of a national ID program arguably has some benefits if such a program is implemented responsibly. ${ }^{143}$ However, the trouble lies in the implementation of such programs in terms of the danger of overextension that could ultimately lead to the deprivation of liberty. If a person is required to carry identification at all times otherwise be subject to arrest, this constitutes a substantial restraint on liberty. If, on the other hand, a person is required to show identification upon entering a specific public place, such as a stadium for a large sporting event, or otherwise be denied admittance, then the person's liberty is not unduly restrained since the potential damage that would result in the event of an attack would be enormous in such a public arena.

The manner element in the First Amendment context addresses restrictions on the demonstration of speech. ${ }^{144}$ The Fourth Amendment parallel concerns the manner of governmental action. Manner is a broad category that encompasses both the manner of any government surveillance and also the level of cause the government has to conduct a given action. The manner element assesses whether the government conducted its actions utilizing the appropriate standard of reasonable suspicion or probable cause given the circumstances. If a scenario poses an imminent threat to national security such that the need for action outweighs the inconvenience to citizens, law enforcement should be held to a reasonable suspicion standard. Probable cause would be difficult to establish and may subject the country to attack.

143. See Daniel J. Steinbock, National Identity Cards: Fourth and Fifth Amendment Issues, 56 FLA. L. Rev. 697, 701 (2004).

144. Clark v. Cmty. for Creative Non-Violence, 468 U.S. 288, 294 (1984). 
Reasonable suspicion prevents the government from simply "spying" on its citizens. However, additional formalities associated with reasonable suspicion may be desired.

\section{B. Application of Fourth Amendment Analysis}

Under the proposed framework, the sneak and peek provision as enacted under the PATRIOT Act would be unconstitutional. The time requirement provides for giving notice within a reasonable period of executing a sneak and peek warrant; however, the provision applies to one's home and the manner allows for entry into one's home without any prior announcement. A person may not know his or her personal belongings were seized from his or home until months after the search.

Although civil libertarians may criticize the approach since it does not enforce a strict scrutiny standard, ${ }^{145}$ it is important to note that " $[\mathrm{w}]$ hile the Constitution protects against invasions of individual rights, it is not a suicide pact." ${ }^{\prime 46}$ National security and privacy must co-exist. Privacy may increase or decrease relative to national security concerns, but that does not automatically mean that privacy rights are being extinguished.

In spite of the natural dynamic relationship between national security and privacy, it is somewhat unsettling to consider the potential for abuse. It appears as though one can make a case that national security crises result in collateral damage to privacy rights. However, Fourth Amendment jurisprudence concerning domestic policy issues has led to arguably similar erosions. Traditional Fourth Amendment jurisprudence and the response to current national security concerns have dovetailed. Therefore, erosions of privacy can occur on multiple fronts, and it is myopic to focus solely on the national security element.

\section{CONCLUSION}

When Congress's exercise of one of its enumerated powers clashes w/one of the individual liberties protected by the Bill of Rights, it is our "delicate and difficult task to determine whether the resulting restriction on freedom" can be tolerated. ${ }^{147}$

145. See Amitai Etzioni, Implications of Select New Technologies for Individual Rights and Public Safety, 15 Harv. J.L. \& Tech. 257, 259 (2002).

146. See Kennedy v. Mendoza-Martinez, 372 U.S. 144, 160 (1963).

147. United States v. Robel, 389 U.S. 258, 264 (1967). 
Given the history of the Fourth Amendment, it would be inaccurate to claim that the PATRIOT Act alone results in collateral damage to civil liberties. Although there are some elements pointing toward such a phenomenon, there are also elements demonstrating that Fourth Amendment interpretation has been twisted over time to meet the needs of a given scenario. Generally speaking, restrictions of civil liberties in response to national security breaches have thus far generated a potential hastening of an erosion of civil liberties versus causing the erosion itself.

The only way to accurately determine a proper balance between national security and privacy is to recognize that judicial, legislative, and or executive action may affect the balance. Although some government actions are directly related to national security interests, others are not. The gradual erosion of privacy began long before the enactment of the PATRIOT Act. In order to hold government accountable, society must be cognizant of the underlying history and judicial trends.

The suggested framework providing for reasonable time, place, and manner restrictions on government actions provides a potentially useful and instructive method for analysis. The balance between national security and privacy is dynamic and shifts in response to events. Although the scale may tip temporarily toward national security, that does not mean that civil liberties are being permanently sacrificed. On the other hand, current governmental actions and the nature of the War on Terror may have established a new equilibrium. 